\title{
Quality of Underground Well Water in Obiagu Area, Enugu State, Nigeria
}

\author{
Innocent Izuchukwu Ujah ${ }^{1 *}$, Nnenna Onuabuchi Ani ${ }^{1}$, Chukwunonso Anthony Nsude ${ }^{1}$, Uchen- \\ na Blessing Alozieuwa ${ }^{2}$, Chukwuebuka Kenechukwu Onyishi ${ }^{1}$ and Innocent Oluwaseun Ok- \\ pako $^{3}$
}

${ }^{1}$ Department of Applied Biochemistry, Enugu State University of Science and Technology, Nigeria

${ }^{2}$ Department of Biochemistry, , Veritas University, Nigeria

${ }^{3}$ Department of Medical Biochemistry, Delta State University, Nigeria

*Corresponding author: Innocent Izuchukwu Ujah, Department of Applied Biochemistry, Faculty of Applied Natural Sciences, Enugu State University of Science and Technology, Enugu, Enugu State, Nigeria.

To Cite This Article: Innocent Izuchukwu Ujah, Nnenna Onuabuchi Ani, Chukwunonso Anthony Nsude, Quality of Underground Well Water in Obiagu Area, Enugu State, Nigeria. Am J Biomed Sci \& Res. 2021 - 12(2). AJBSR.MS.ID.001737. DOI: 10.34297/AJBSR.2021.12.001737.

Received: 眥 January 28, 2021; Published: 耕 March 16, 2021

\begin{abstract}
This study was aimed at assessing the quality of underground well water in Enugu metropolis. Samples were collected from closed wells at a depth of 120-150 m high from the ground level into clean sterile plastic containers from four (4) different locations: Old artisan, Oriefete, Obiagu and Ani Street. These samples were taken to laboratory for physiochemical parameters (pH, conductivity, total dissolved solids, total suspended solid, nitrate, acidity and alkalinity), heavy metals (arsenic, mercury and chromium) status and bacteriological quality. Results showed a huge nonconformity from safe standard limit established by the World Health Organization (WHO) as some of the values were much higher. The presence of some pathogenic bacteria (Escherichia coli, Clostridium perfringens, Streptococcus faecalis, Enterobacter aerogenes) is also a major indicator of bacterial contamination. This implies that the underground water well of the selected areas is not safe and it needs some great deal of treatment before consumption.
\end{abstract}

Keywords: Underground well water, Conductivity, Acidity, Alkalinity, Heavy metals, Bacteria

\section{Introduction}

For the sustenance of life, the essentiality of water cannot be overestimated [1] Underground well water provides a dependable alternative to surface water for drinking, irrigation and industrial usage [2]. Contamination of underground water is not as common as surface water, however upon pollution, treatment is usually demanding and sluggish [3]. Pollution of underground water is one of the majour environmental challenges today arising from improper and indiscriminate disposal of sewage, industrial and chemical waste [4]. These sources of contamination may affect key organic, physical and chemical variables of groundwater [5]. Impurities that are mainly linked with underground water pollution include nitrates, pesticides and faecal coliforms. Also, anthropogenic activ ities such as land use and the intervention in the natural flow patterns are often connected to groundwater pollution [6].

One of the fundamental rights of human being is access to clean and free drinking water. An estimated 780 million people do not have opportunity to pure and non-contaminated water with about 2.5 billion people not having appropriate hygiene [7]. Consequently, an estimated 6-8 million people pass on annually due to water borne diseases and tragedy. Water quality is a growing concern through the developing world and sources of drinking water are constantly under threat from contamination. This has both public health consequences as well as socioeconomic implications. There is thus the need to assess water quality of underground before hu- 
man consumption. Many developing countries however lack the resources required to carry out water standard evaluation due to financial and poor-quality control issues [8].

For these emerging countries, material and bacteriological evaluation of water standard could serve as an alternative for examining potential corruption in underground water and help administrators in determining the effectiveness of managerial programs in managing water resources [9]. These methods are accepted by the WHO which has enumerated its health-based indices for numerous possible water contaminants. These indices could be any measurable health, water standard or performance variables that are established based on assessment of safety and risk waterborne hazards [10]. The health-based targets for contaminants provide a framework for achieving safe drinking water, creating a water safety plan and maintaining water surveillance by policymakers. The bacterial and heavy metal content of well in Nigeria have been reported to be unsatisfactory [11]. Consequently, assessment of water standard should be a foremost agenda globally [10].

Enugu is one of largest and historical states in Nigeria. As population grows by day, the challenge to meet user demands of water also increases. Inhabitants of Enugu metropolis currently depend largely on drinking water transported from boreholes at 9th mile corner, Udi local government area which is about $8 \mathrm{~km}$ from the city [12]. This water source is not economical and not sufficient to meet the domestic and other needs of the residents. Residents thus resort to underground well water which may be contaminated as an alternate source of water. This study thus aimed to analyze the underground well water in Enugu metropolis.

\section{Materials and Methods}

\section{Study Area}

Enugu is the county town of Enugu State, South-Eastern Nigeria with a population of 722,000 [13], and density approximate of $6,400 / \mathrm{km} 2$. The geographical coordinates of the study area are $6^{\circ}$ $21^{\prime} \mathrm{N}$ and $6^{\circ} 30^{\prime} \mathrm{N}$ and $7^{\circ} 26^{\prime} \mathrm{E}$ and $7^{\circ} 30^{\prime} \mathrm{E}$. Enugu has a rainforest warm weather. Average yearly rainfall lies between $1600 \mathrm{~mm}$ and $2500 \mathrm{~mm}$ about four months of dry season, which has $29 \mathrm{~mm}$ of rainfall [14]. Average monthly temperature falls between $27^{\circ} \mathrm{C}$ and $29^{\circ} \mathrm{C}$, vegetation type of the study area is rainforest savanna [15]. Nyaba, Ekulu, Idaw, Aria, Ogbete and Asata are the main rivers in the city which originates westward from the base of the Udi escarpment and flows eastwards into the cross river. Asata River a third order stream, has an area of about $40 \mathrm{sqkm}$ and is a tributary of the Ekulu River. The Asata river basin falls within the large Abonie basin. The largest body of water in Enugu urban is the Ekulu River, and it is large enough to contribute to part of the city's local water supply [13] (Figure 1).

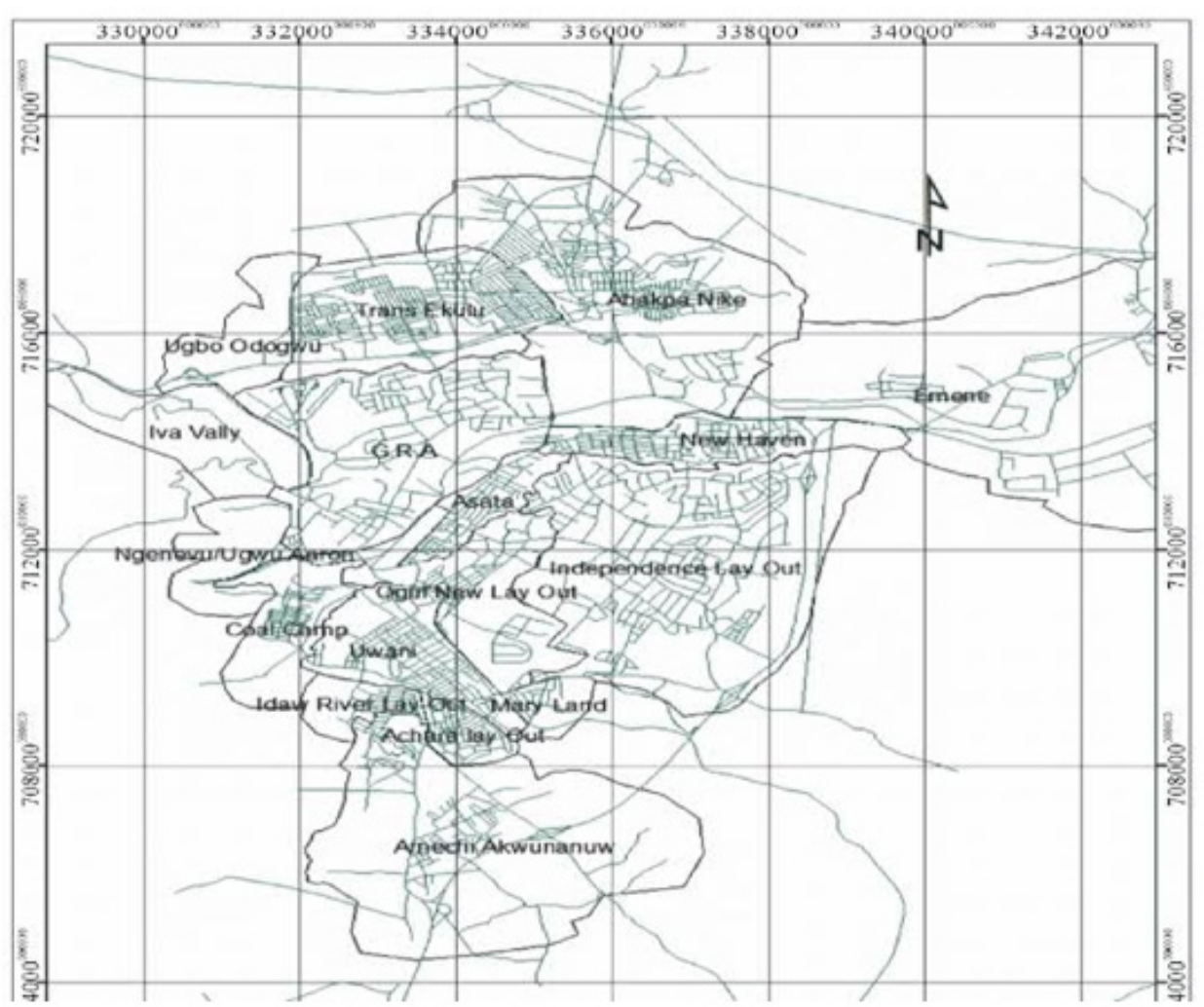

Figure 1: Map of Enugu metropolis showing settlements Source [33] 


\section{Sample Collection}

The underground well water was taken from closed wells at a depth of 120 - $150 \mathrm{~m}$ high from the ground level. Four samples were collected in clean sterile plastic container from four different locations and were taken to laboratory for determination of the physiochemical parameter, heavy metal and bacteriological quality.

\section{Sample Analysis}

On-site analyses of $\mathrm{pH}$, conductivity, were carried out at the site of sample collection following the standard protocols and methods of American Public Health Organization (APHA) and American Society for Testing and Materials (ASTM) using different calibrated standard instruments [16]. The pH of the water samples was measured by using a pH meter (model HI 98130 HANNA, Mauritius, Iramac Sdn. Bhd.). The conductivity of the samples was measured using a conductivity meter (model HI 98130 HANNA, Mauritius, Iramac Sdn. Bhd.). Laboratory analyses of Total Solids (TS), Total Suspended Solids (TSS) and Total dissolved solids (TDS) in water samples were carried out by the filtration process [17]; alkalinity and acidity [18] and nitrate [19].

The analyses of heavy metals Chromium [20], Arsenic [21] and Mercury [21] were carried out based on ASTM standards, which Table 1: Micro-organisms found. are approved by APHA using Flame Atomic Absorption Spectrometer (FAAS). For analysis of Chromium direct extraction/air acetylene flame method was used, while manual hydride generation AAS method was used in determination of Arsenic in the samples. Cold-vapor AAS method was applied in determination of Mercury. The standard solution for each tested element was prepared according to its concentration and used to calibrate the system before analyzing each water sample. The results were recorded automatically on a computer connected with the AAS system. Microbial analyses were carried out according to procedures of [22].

\section{Questionnaire Administration}

Twenty structured questionnaires were administered to respondents to ascertain consumption of the underground water, sources of contamination of the underground water and possible health consequences related to the consumption of such water.

\section{Results}

The physiochemical parameters including $\mathrm{pH}$, conductivity, total dissolved solids, total suspended solid, nitrate, acidity and alkalinity are showed in (Figures 1-6 \& 7) depicts the level of heavy metals while (Table 1 ) revealed the bacteria present in water samples (Tables 2-5).

\begin{tabular}{|c|c|}
\hline Sampling Towns & Microorganisms \\
\hline Old artisan & Escherichia coli, Clostridium perfringens, \\
Oriefete & Streptococcus faecalis, Enterobacter aerogenes \\
\hline Obiagu & Escherichia coli, Clostridium perfringens, \\
& Streptococcus faecalis, Enterobacter aerogenes \\
\hline Ani Street & Escherichia coli, Clostridium perfringens, \\
& Streptococcus faecalis, Enterobacter aerogenes \\
\hline & Escherichia coli, Clostridium perfringens, \\
\end{tabular}

Table 2: The safe limits of WHO for determining drinking water quality.

\begin{tabular}{|c|c|}
\hline Parameter & WHO Limits \\
\hline $\mathrm{pH}$ & $6.5-8.5$ \\
\hline Acidity & - \\
\hline Alkalinity & 600 \\
\hline Conductivity $(\mathrm{s} / \mathrm{m})$ & 250 \\
\hline $\mathrm{TSS}$ & - \\
\hline $\mathrm{TS}$ & - \\
\hline $\mathrm{TDS}(\mathrm{mg} / \mathrm{L})$ & 1000 \\
\hline $\mathrm{Nitrate}(\mathrm{mg} / \mathrm{L})$ & 50 \\
\hline $\mathrm{Cr}(\mathrm{mg} / \mathrm{L})$ & 0.05 \\
\hline $\mathrm{As}(\mathrm{mg} / \mathrm{L})$ & 0.01 \\
\hline $\mathrm{Hg}(\mathrm{mg} / \mathrm{L})$ & 0.006 \\
\hline
\end{tabular}


Table 3: Sources of contamination of the underground water from the questionnaire.

\begin{tabular}{|c|c|c|c|}
\hline & Frequencies Yes & Frequencies No & No. of Respondents \\
\hline Is there any industrial waste close to the underground water & $5(-25 \%)$ & $9(-75 \%)$ & 20 \\
\hline Is there any farm close to the underground water & $9(-45 \%)$ & $11(-55 \%)$ & 20 \\
\hline Is there any municipal waste close to the underground water & $12(-60 \%)$ & $8(-40 \%)$ & 20 \\
\hline Is there market location close to the underground water & $12(-60 \%)$ & $8(-40 \%)$ & 20 \\
\hline
\end{tabular}

Table 4: Uses of the underground water from the questionnaire survey.

\begin{tabular}{|c|c|c|c|}
\hline Uses & Frequencies Yes & Frequencies No & No of respondents \\
\hline Cooking & $20(-100 \%)$ & 0 & 20 \\
\hline Bathing & $20(-100 \%)$ & 0 & 20 \\
\hline Drinking & $2(-10 \%)$ & $18(-90 \%)$ & 20 \\
\hline Washing & $12(-60 \%)$ & $8(-40 \%)$ & 20 \\
\hline
\end{tabular}

Table 5: Possible health effects from the use of the underground water from the questionnaire survey.

\begin{tabular}{|c|c|c|c|}
\hline & Frequencies Yes & Frequencies No & No of respondents \\
\hline Do you have itches and scratches after using the underground water & $2(-10 \%)$ & $18(-90 \%)$ & 20 \\
\hline Have you vomited after drinking the underground water & $2(-10 \%)$ & $18(-90 \%)$ & 20 \\
\hline $\begin{array}{l}\text { Have you experienced mouth ulcer which may be attributable to the underground } \\
\text { water }\end{array}$ & $2(-10 \%)$ & $18(-90 \%)$ & 20 \\
\hline
\end{tabular}

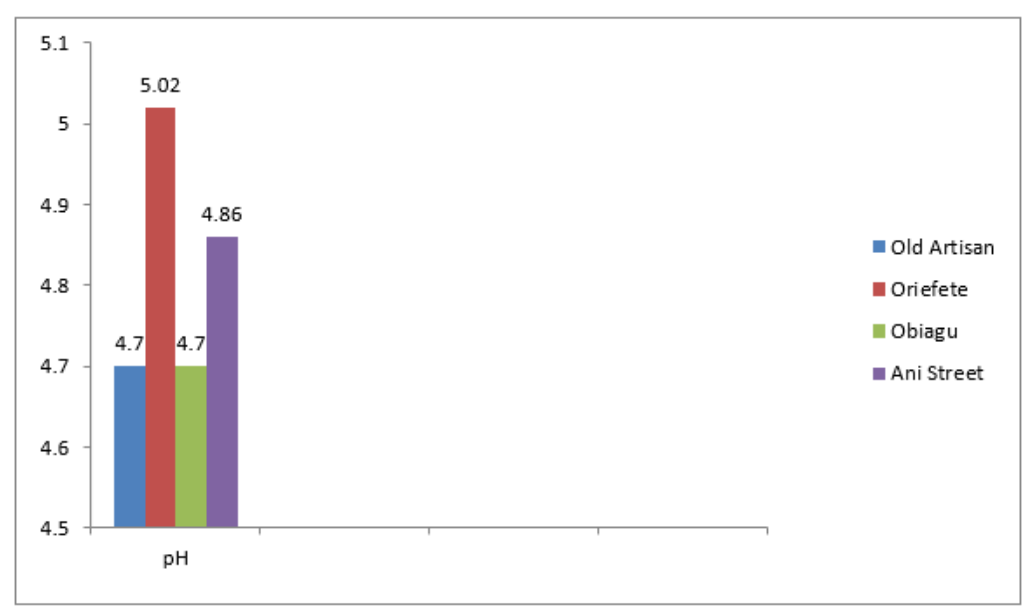

Figure 2: The $\mathrm{pH}$ of water samples.

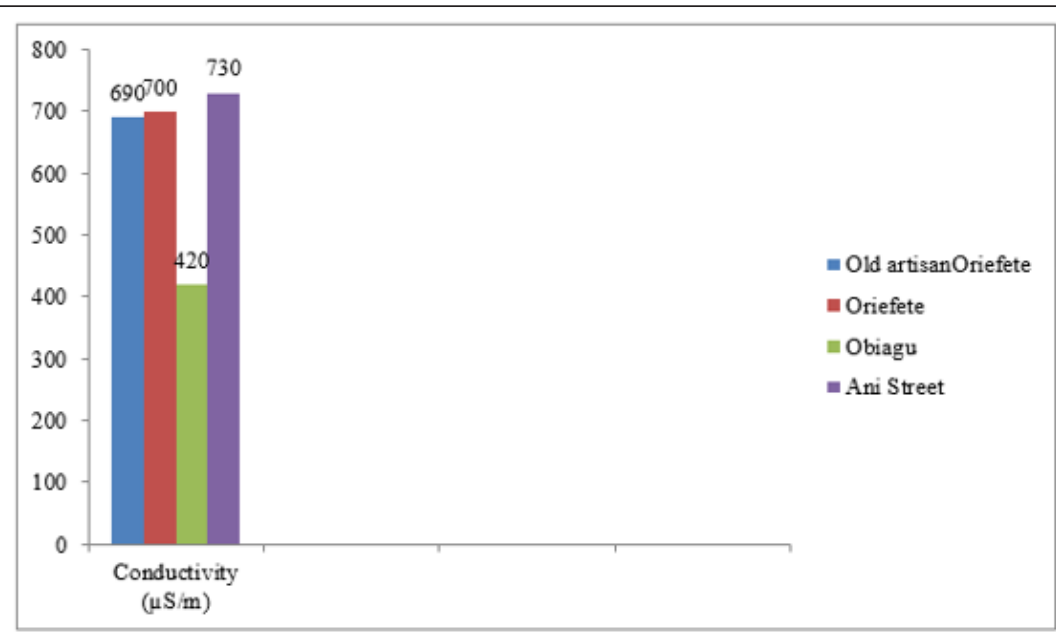

Figure 3: The conductivity of water samples. 


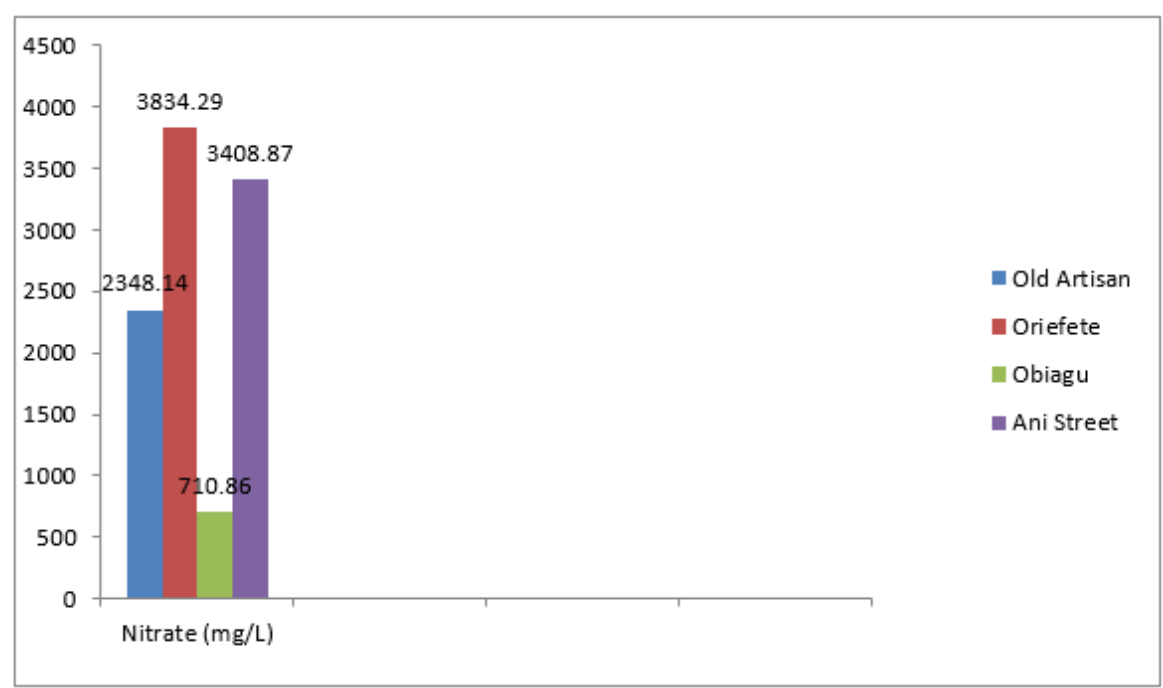

Figure 4: The concentration of nitrate in water samples

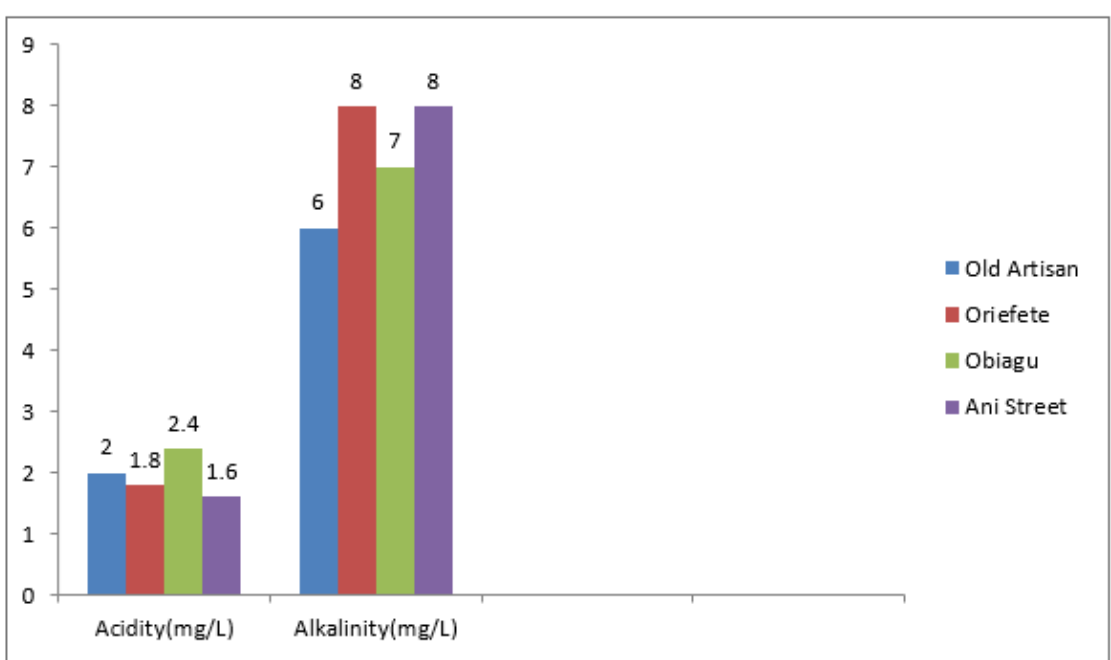

Figure 5: The acidity and alkalinity of water samples.

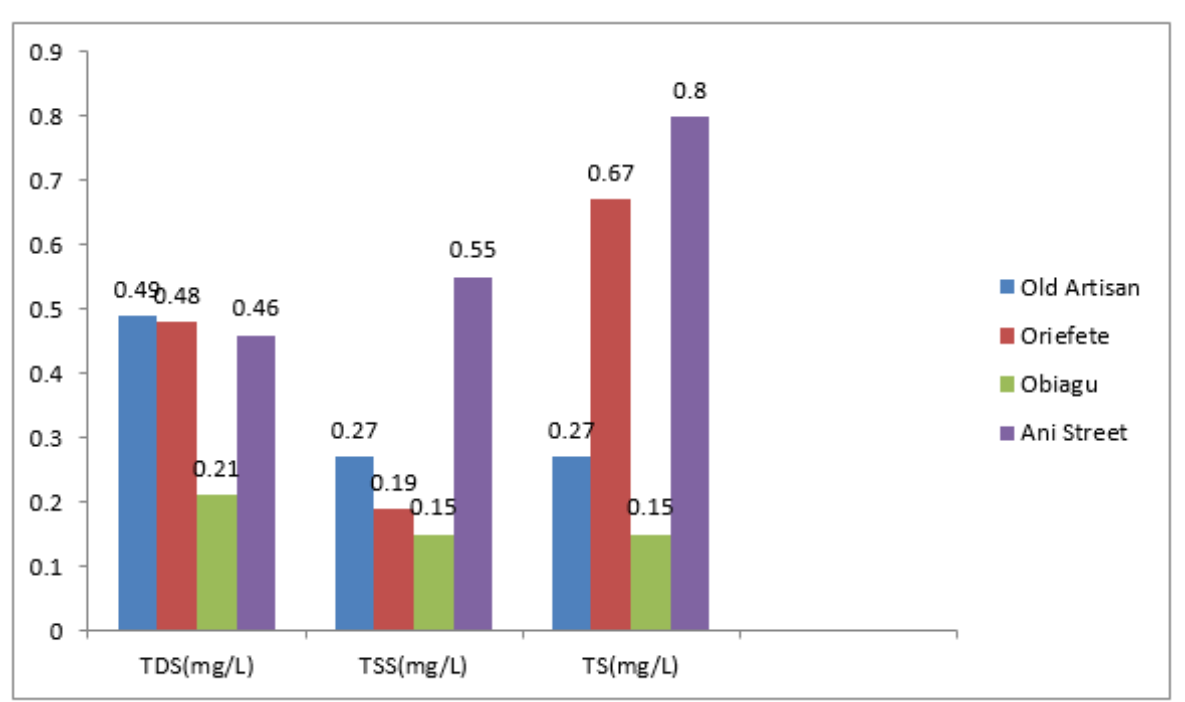

Figure 6: The TDS, TSS and TS in water samples. 


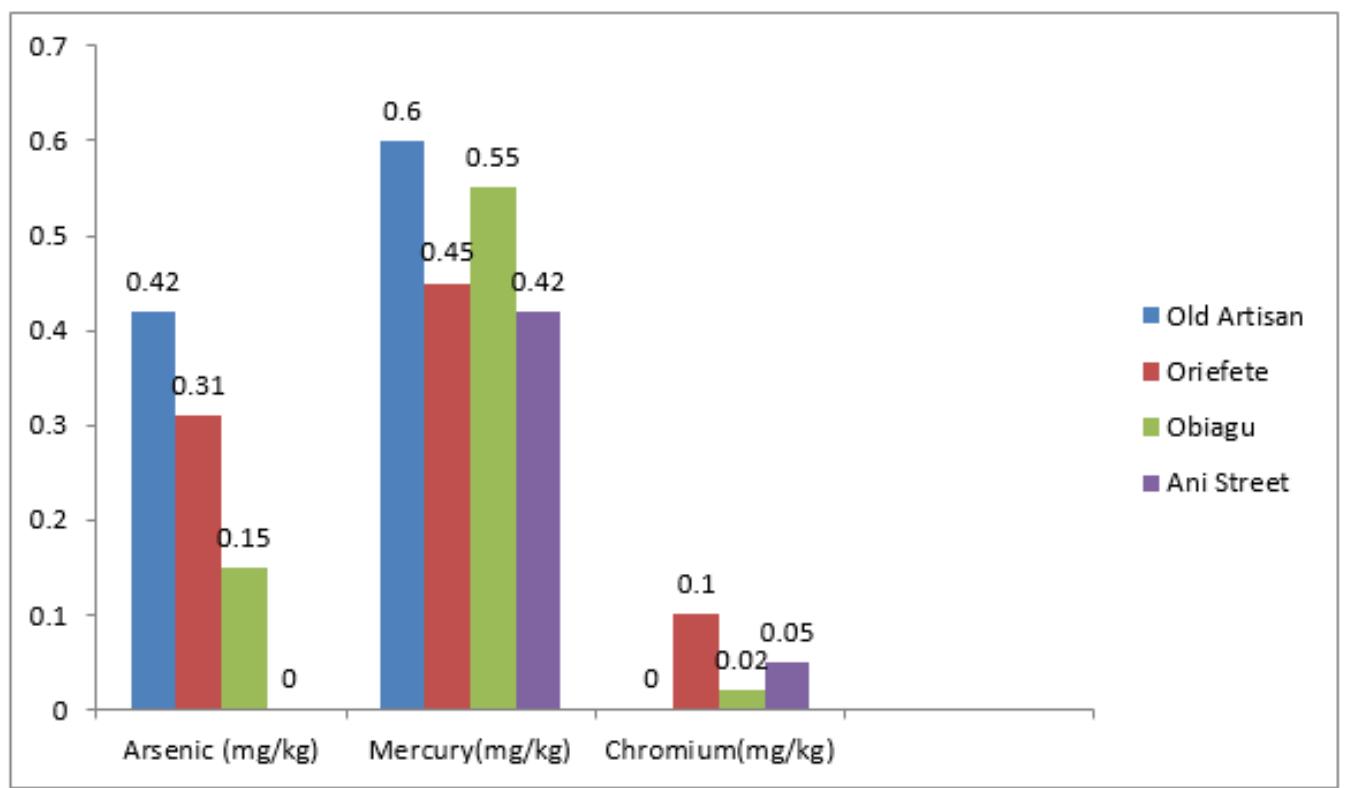

Figure 7: Levels of heavy metals in water samples.

\section{Discussion}

pH value below 6.5 and above 8.5 indicates acidic water and basic water respectively. The $\mathrm{pH}$ of the study area ranges from 4.70 to 5.02 while the standard range is 6.5-8.5. Old artisan (4.70), Oriefete (5.02), Obiagu (4.70) and Ani Street (4.86) indicate acidic water having $\mathrm{pH}$ below 6.5. $\mathrm{pH}$ has no direct adverse effects on health [23]. However, acidic water can lead to corrosion of metal pipes and plumping system.

Electric current carrying capacity of any medium defines its conductivity. Dissolved solids such as calcium, chloride, and magnesium in water samples contribute to the conductivity of water. The values of conductivity obtained were $(690,700,420$ and 730 $\mu \mathrm{S} / \mathrm{cm}$ ), which generally were much higher than the WHO standard limit of $250 \mu \mathrm{S} / \mathrm{cm}$. Conductivity gives an indication of the mineral content of the study area. There may be no direct impact of conductivity on human health, but it is however used to ascertain the mineralization rate (existence of minerals such as potassium, calcium, and sodium) and determining the quantity of chemical reagents used to treat this water [24]. Elevated conductivity could depreciate the tasteful value of the water by giving mineral taste to the water. Water with high conductivity is important in industry and agriculture as this may cause corrosion of metal surface of equipment such as boiler. This is also applicable to home appliances such as water heater system and faucets. Excessive conductivity may also terminate food-plant and habitat-forming plant species [25].

Nitrate in form of nitrogen is frequently connected with groundwater pollution [26]. In adults' nitrate is not associated with any health problem, however ingestion by infants can deplete the oxygen levels in the blood, which could lead to fatality [6] All underground well water samples analyzed in present study (Figure 3) contained varying concentrations $(2348.14,3834.29,710.86$ and $3408.87 \mathrm{mg} / \mathrm{L}$ ) of nitrate that are far above the WHO established maximum allowable threshold for drinking water of 50 $\mathrm{mg} / \mathrm{L}$ (WHO, 2011). This high concentration of nitrate observed may be due to market location close to the underground water or industries dealing with organic materials in the area. The ranges of alkalinity found in present study lie in between 6-8 $\mathrm{mEq} / \mathrm{L}$. The standard values as prescribed by the WHO are between 200-600 $\mathrm{mEq} / \mathrm{L}$ [27]. Therefore, the total alkalinity is below the prescribed limits. Carbonates ( $\left.\mathrm{HCO}^{-}, \mathrm{CO} 32^{-}\right)$and hydroxides $(\mathrm{OH}-)$ are the main causes of alkalinity in ground water [6], it depicts the acid neutralizing ability of the water. Rocks contributes to the acidity to underground water, and the presence of rocks may have resulted in the low alkalinity of the study area [6], From the results of the Total Dissolved Solids (TDS), Total Solids (TS) and Total Suspended Solids (TSS) given in Figure 5, TDS of study area were between 0.21-0.49 mg/l, TS 0.15-0.80 mg/l and TSS 0.15-0.55 mg/l. Total dissolved solids (TDS) in drinking water wastes form market location close to the underground water, soak away or industries dealing with organic materials in the area. High concentrations of TDS may confer undesirable taste, odour and colour on water, which will have adverse reactions to the consumer [28]. High level of TDS in water used for drinking purposes leads to many diseases which are not water-borne but due to excess salts [29]. The TDS values were far negligible compared to the maximum standard level of 1000 $\mathrm{mg} / \mathrm{l}$ (WHO, 2011). 
Heavy metals in drinking water higher than a certain required level can be detrimental to human health. It is thus necessary to assay for heavy metals in drinking water is an important parameter, as most of the studies on drinking water quality centered on investigation of heavy metals. Heavy metals tend to bioaccumulate in human body parts and disrupt their normal physiological functions. In this study, the results of heavy metals such as $\mathrm{Cr}$, As, and $\mathrm{Hg}$ (Table 1) were higher than recommended levels set by WHO (Table 2). As was not found in Ani Street, however $0.42,0.31$ and $0.15 \mathrm{mg} / \mathrm{L}$ were recorded respectively in samples collected from Old Artisan, Oriefete and Obiagu; $\mathrm{Hg}$ was present in all sample with values ranging from $0.42-0.60 \mathrm{mg} / \mathrm{L}$, this high levels of $\mathrm{Hg}$ in samples may arise from market market location close to the underground water soak away or industries dealing with organic materials in the area. Chromium (Cr) was found in all except Old Artisan, the levels of $\mathrm{Cr}$ found in Obiagu $(0.02 \mathrm{mg} / \mathrm{L})$ and Ani Street $(0.05 \mathrm{mg} / \mathrm{L})$ were within WHO's safe limit of $0.05 \mathrm{mg} / \mathrm{L}$, however Oriefete $(0.10 \mathrm{mg} / \mathrm{L})$ is much higher.

The pollution from Cr, may be from industrial sources. Cardiovascular diseases, kidney-related problems, neurocognitive diseases, and cancer are related to the traces of chromium $(\mathrm{Cr})$ (Rahmanian et al., 2015). Recently, arsenic (As) has attracted global attention for its notoriety in human (WHO, 2011). Arsenic (As) and mercury $(\mathrm{Hg})$ can cause serious dermatological effects, tumour damage to kidney and liver [10]. In fact, Hg and inorganic Hg compounds are classified in group 3 carcinogens [30]. The use of index and indicator organisms to assess the microbiological and sanitary quality of waters is an accepted method and has been in practice for nearly a hundred years. The most widely used indicators are coliforms (total coliforms), faecal or thermotolerant coliforms, Escherichia coli, enterococci (faecal streptococci or intestinal enterococci) and bacteriophages [31]. These microorganisms can be used as indicators of faecal pollution.

In present study, Escherichia coli, Clostridium perfringens, Streptococcus faecalis and Enterobacter aerogenes were present in all water samples. These enteric microorganisms (Escherichia coli, Streptococcus faecalis and Enterobacter aerogenes) are excreted in the faeces of infected individuals or animals and may directly or indirectly contaminate water intended for human consumption [32]. Heavy rains contributed to the run-off of water from open defecation site in ground water. The result of the questionnaire survey shows that many of the respondents use the underground well water for cooking and bathing. This may have some health implications as the contaminants in these waters have been associated with health conditions [34].

\section{Conclusion}

The large chunk of analyses done on water samples in this study did not conform to WHO standard requirements for drinking water.
This calls for approach and design of regular treatment procedures by regulatory authorities concerned to ensure good water quality before underground water in these areas can be considered for drinking or even bathing or washing as the high concentration of Arsenic and acidic $\mathrm{pH}$ for example may cause serious skin problems and corrosion of metallic materials respectively.

\section{References}

1. Yerramsetty A, Srinivasa GV (2013) A study on physico-chemical characteristics of groundwater in the industrial zone of Visakhapatnam, Andhra Pradesh. American Journal of Engineering Research 2(10): 112116.

2. Arslan H (2012) Spatial and temporal mapping of groundwater salinity using ordinary kriging and indicator kriging: The case of Bafra Plain, Turkey. Agriculture and Water Management 113: 57-63.

3. Agbaire PO, Oyibo IP (2009) Seasonal variation of some physico-chemical properties of borehole water in Abraka, Nigeria. African Journal of Pure and Applied Chemistry 3(6): 116-118.

4. Obot EE, Edi DB (2012) Spatial variation of borehole water quality with depth in Uyo Municipality, Nigeria. Global Journal of Environmental Science and Management 1: 1-9.

5. Sappa G, Ferranti F, Ergul S, Ioanni G (2013) Evaluation of the groundwater active recharge trend in the coastal plain of Dar es Salaam (Tanzania). Journal of Chemical and Pharmaceutical Research 5(12): 548-552.

6. Saana SB, Fosu SA, Sebiawu GE, Jackson N, Karikari T, et al. (2016) Assessment of the quality of groundwater for drinking purposes in the upper West and Northern regions of Ghana. Springerplus 5: 2001.

7. Rahmanian N, Hajar S Ali B, Homayoonfard M, Ali N J, Rehan M, Sadef Yand Nizami, et al. (2015) Analysis of physiochemical parameters to evaluate the drinking water quality in the state of Perak, Malaysia. Journal of Chemistry 15: 1-10.

8. Hoko Z (2005) An assessment of the water quality of drinking water in rural districts in Zimbabwe. The case of Gokwe South, Nkayi, Lupane, and Mwenezi districts. Physics and Chemistry of the Earth, Parts ABC 30(11-16): 859-866.

9. Sadiq R, Haji S A, Cool G, Rodriguez MJ (2010) Using penalty functions to evaluate aggregation models for environmental indices. Journal of Environmental Management 91(3): 706-716.

10. World Health Organization WHO (2011) Guidelines for Drinking-Water Quality. Geneva, Switzerland: WHO Press

11. Izah SC, Charabarty N, Srivastar AL (2016) A review of heavy metal concentration in potable water sources in Nigeria: Human health effects and mitigating measures. Exposure Health 8(2): 285 - 304.

12. Ugwuoti A I, Onah E, Ojinnaka O (2019) Improving Enugu urban water sourcing and distribution using geospatial technologies. FIG Working Week 2019 Geospatial information for a smarter life and environmental resilience. Hanoi, Vietnam.

13. Shu EN, Onyemelukwe NF, Nwodo ES, Otuu FC, Ilouno L, et al. (2019) Unwholesome herbal medicines marketed in Enugu metropolis, Enugu State, South Eastern Nigeria: Public health implications. Journal of Environmental Science and Public Health 3(2): 122-132.

14. Umeuduji JE (1994) Analysis of topological characteristics and drainage parameters in the Aboine Basin of Nigeria. An unpublished Ph. D dissertation, Department of Geography, University of Nigeria, Nsukka.

15. Chima GN, Ogbonna CE, Nwankwo, IU (2009) Effects of urban wastes on the quality of Asata River in Enugu, South Eastern Nigeria. Global Journal of Environmental Science 8: 31-39. 
16. J DeZuane (1997) Handbook of drinking water quality. United States: John Wiley \& Sons.

17. American Public Health Association APHA (1995) Standard Methods: For the examination of water and wastewater. United States: APHA Publication.

18. Sawyer CN, Mc Carty, PL Parkin C F (1994) Chemistry for Environmental Engineering. United States: Mc Graw-Hill.

19. Baezzat MR, Parsaeian G, Zare MA (2011) Determination of traces of nitrate in water samples using spectrophotometric method after its preconcentration on microcrystalline naphthalene. Quimica Nova 34(4): 607-609.

20. American Society for Testing and Materials, ASTM (2012) Standard Test Methods for Chromium in Water. ASTM International, West Conshohocken, USA.

21. American Society for Testing and Materials, ASTM (2012) Standard Test Methods for Total Mercury in Water. ASTM International, West Conshohocken, United States.

22. Köster W, Egli T, Ashbolt N, Botzenhart K, Burlion N, et al. (2003) Analytical methods for microbiological water quality testing. In Assessing Microbial Safety of Drinking Water. Improving Approaches and Method. London, UK: IWA Publishing.

23. Parvez N, Pritul AS (2018) Analysis of ground water quality: A case study in the Savar (Akrain) Area. Journal of Water Resources and Pollution Studies 3(3): 67-75.

24. Khan S, Shahnaz M, Jehan N, Rehman S, Shah MT, et al. (2013) Drinking water quality and human health risk in Charsadda district, Pakistan. Journal of Cleaner Production 60: 93-101.

25. Katsoyiannis IA, Zouboulis AI (2003) Removal of uranium from contaminated drinking water: a mini review of available treatment methods. Desalination and Water Treatment 51(15): 2915-2925.
26. Böhlke JK, Smith RL, Miller DN (2006) Ammonium transport and reaction in contaminated ground water-application of isotope tracers and isotope fractionation studies. Water Resources Research 42: 54.

27. Ashfaq A, Ahmad F (2014) Study on assessment of underground water quality. International Journal of Current Microbiology and Applied Science 3(9): 612-616.

28. Spellman FR, Drinan JE (2012) The drinking water handbook ( $2^{\text {nd }}$ edn), CRC Press, Boca Raton, USA.

29. Parihar SS, Kumar A, Kumar A, Gupta RN, Pathak M, et al. (2012) Physico-chemical and microbiological analysis of underground water in and around Gwalior City, MP, India. Research Journal of Recent Sciences 1(6): 62-65.

30. Jia W, Li C, Qin K, Liu L (2010) Testing and analysis of drinking water quality in the rural area of High-tech District in Tai'an City," Journal of Agricultural Science 2(3): 155 - 157.

31. Figueras MJ, Borrego JJ (2010) New perspectives in monitoring drinking water microbial quality. Int J of Environ Res Public Health 7: 4179-4202.

32. Asbolt NJ (2004) Microbial contamination of drinking water and disease outcomes in developing regions. Toxicology 198(1-3): 229-238.

33. Ejiagha IR, Ojiako JC, Eze CG (2012) Accessibility analysis of healthcare delivery system within Enugu urban area using geographic information system. Journal of Geographic Information System 4: 312-321.

34. American Society for Testing and Materials, ASTM (2008) Standard Test Methods for Arsenic in Water. ASTM International, West Conshohocken, USA. 